\title{
Understanding The Restavèk Phenomenon in Haiti Through Storytelling and Film
}

\author{
Marcela Moyano \\ St. Thomas University, Miami Gardens, Florida, USA
}

\begin{abstract}
Known as the Pearl of the Antilles, Haiti was the first black republic to win its independence from the French in an uprising by slaves. Two hundred years after the revolt, Haiti's children, the most vulnerable population of the nation, endure modern day slavery. Extreme social, economic, and political instability have led the country to adopt and accept this practice. This qualitative study reveals audiences' narratives of their experiences as guardians of Restavèks and their reflections after watching the documentary film Blooming Hope (2010). The documentary features Tata Dumasie, an artisan woman who narrates her life story growing up as a Restavèk. This ethnographic research concludes that documentary films serve as tools for popular education. Furthermore, narrative discourse can reconstruct identities of former Restavèks and positively transform guardians' perceptions of the Restavèk phenomenon.
\end{abstract}

Keywords: Restavèk, narrative discourse, Haiti

\section{Understanding the Restavèk Phenomenon in Haiti Through Storytelling}

This research paper originates after several screenings of the documentary Blooming Hope (2010) in rural Haiti and in South Florida. Audience members approached the film's director to engage in deeper conversation about the Restavèk phenomenon. As a result, the researcher designed a qualitative study through in-depth personal interviews with six audience members who share their most intimate untold narratives of their experiences as Restavèks' guardians. This study is the result of a storytelling process that aids participants to reconcile their negative attitudes towards their domestic child servants. Finally, this paper demonstrates the power of documentary films to scrutinize social issues commonly accepted and how such representation of hidden social issues can result in social transformation.

\section{Historical Context of Haiti and Slavery}

In an attempt to understand the root cause and context of child-indentured servitude in Haiti, the researcher studies historical texts of the French colonization and the slaves' revolt to gain the nation's independence. These texts demonstrate the conflict between the powerful class, predominantly French and Caucasian decent, and the disadvantaged class, predominantly slaves of African descent. Furthermore, the author presents social and economic indicators of the Haitian society.

Haiti constitutes one third of the Island of Hispaniola. The French colonization was remarkable in Saint

Marcela Moyano, Assistant Professor, Institute for Communication, Entertainment \& Media School of Leadership Studies, St. Thomas University. 
Domingue due to the large numbers of people who were brought from Africa as slaves to work the land and to serve the dominant colonial class. Saint Domingue became the largest producer of sugar cane and coffee as the result of the exploitation of the land and extreme human labor (Moyano \& Rosero, 2010).

The independence of Haiti was the result of a revolt of slaves who did not tolerate any longer the abuse and subjugation of the French colonizer. Bell's All Souls Rising novel illustrates the story of the independence of Haiti. One passage of the novel depicts the main character raising this question: "For all creatures, there is only fertility within their kind... if a white man and a black woman come together, what will you call their offspring? Is it something else or is it human" (Bell, 1995). The problem of racism and discrimination in Haiti is perfectly illustrated in this questioning of human nature based on skin color.

Furthermore, historical records tell the magnificent story of the liberation of the slaves from the French (Dubois \& Garriqus, 2006). In August of 1791, numerous slaves gathered in a Choiseul plantation known as Caiman and carried out a religious ceremony in preparation for the revolt against the French colonists. A black woman slit the throat of a black pig that was sacrificed; the slaves present at the ceremony drank the pig's blood. They all had bristles of the pig that they believed had magical properties and would make them invisible during the revolt. This ritual is known as a voodoo cult that some understand as a night when the African slaves made a pact with the devil. Some blame the cult for the misfortune of the country that has faced extreme political turmoil, continuous generations of dictatorships, natural disasters, and human rights violations.

A few nights after the cult was executed, slaves revolted against the French masters of plantations and their families. One young slave confessed the intention of all slaves to "fight the death against the whites" (Dubois \& Garriqus, 2006, p. 91). A group of slaves who had a torch in one hand and a dagger in the other, and led by a man known as "Boukman", violently massacred all the whites that could not escape through the sugar cane fields. The revolt illustrates the burning of plantations. "Twenty Thousand slaves who were once peaceful and submissive were now cannibals" (Dubois \& Garriqus, 2006, p. 93). The independence concludes on January 1 st of 1804 when Saint Domingue is declared as a free and independent nation.

The history of liberation clearly represents the struggle of the oppressed over the oppressor. Fischer (2004) argued that the truth of the Haitian revolution lies on the displacement of the ruling class of Haiti and former slaves taking power. The disavowal of revolutionary antislavery became an ingredient in Creole nationalism and, eventually, in hegemonic conceptions of modernity (Fischer, 2004, p. 273). A robust comprehension of the liberation of Haiti is vital to reach a deeper understanding of the class struggle that Haiti faces today, which can be merely reduced to a matter of skin color.

The history of Haiti is exemplary of courage and freedom. Haiti is the first country in the world that became an independent nation with a rebellion led by slaves to free themselves from the French colonists. However, the independence was then followed by a demand from the French for reparations of \$28 million for having lost their colony commonly known as the Pearl of the Antilles. This sank Haiti into an endless debt (Bracken, 2006). Many Haitians refer to their lives as living in Iamise, a Creole term that refers to Economic Despair. Today, Haiti is the country with the lowest Gross Domestic Product (GDP) per capita of the Western Hemisphere (United Nations Statistics Division, 2015).

According to the United Nations Statistics Division (2015), 35\% of the Haitian population is comprised by children under 14 years old. Life expectancy is only 61 years old. Haiti has the highest infant mortality rates in the western hemisphere and there is a $2.1 \%$ of the population living with the prevalent HIV virus. $52 \%$ of the population is illiterate. Twenty five percent of children between 5 and 14 years old work (UNICEF, 2015). 
According to UNICEF (2015), approximately 2,000 children are victims of human trafficking taken to Dominican Republic often with their parental/custodian support. Today, approximately 300,000 children are victims of domestic slavery known as Restaveks (End Slavery Now, 2015).

The Haitian population is divided between two social systems (1) comprised of light skinned, French speaking, Catholic, urban residents who hold powerful roles in the workforce and (2) comprised of people of darker skin, Haitian Creole speaking, voodoo practicing, illiterate, rural residents who are severely impoverished (Wagner, 2008). Consequently, the duality between oppressed and oppressor and the dichotomy of power relationship is a clear example of the treatment given to children who are victims of the structural violence in Haiti and the Restavèk phenomenon as one simple example of such class violence (Wagner, 2008). The restavè phenomenon can be best described as the result of a prevalent colonization of the ruling class over the most disempowered group of any nation: its children.

\section{The Haitian Restavèk Phenomenon}

This section of the paper attempts to define the Restavèk Phenomenon and provides facts of the current Haitian Restavèk population. The term Restavèk stems from French rester avec translated as "stay with" (Balsari et al., 2010; Bracken, 2006; Wagner, 2008) and is a historical practice in Haiti to send children away to live with wealthy families who can provide them food and shelter. The social connotation of the restavèk is one who is "motherless or unwanted". Restavèk is a term, which is often used as an insult and characterizes an individual with lack of personality or self empowerment (Campbell, Miers, \& Miller, 2011).

Article I (d) of the UN Supplementary Convention of the Abolition of Slavery, the Slave Trade, and Institutions and Practices Similar to Slavery (1956) defined Child Servitude as:

Any institution of practice whereby a child or young person under 18 years is delivered by either or both his/her natural parents or guardian to another person, whether for reward or not, with a view to the exploitation of the child or young person or of his labor. (p. 3)

Therefore, according to this definition of Child Servitude, the restavèk phenomenon falls under this category of modern slavery.

For the purpose of this study, the person who owns the restavèk children is labeled as guardian. The restavè phenomenon is based on the assumption that the children do not receive monetary compensation for their labor; therefore, caregivers cannot be denominated as employers. Furthermore, the nature of institutionalization of children rests on the belief that guardians compensate children's work through supplying their basic needs as food and shelter.

\section{Theoretical Framework}

The theoretical framework of this paper is based on poplar education and storytelling. The researcher designs the methodology based on these two approaches.

\section{Popular Education}

Popular education is a vehicle of social transformation, which engages learners with usually unheard narratives and personal stories (Freire, 1970). Some of the premises of popular education are: (1) Learner and educator engage in a process of reciprocity benefiting from the educational experience; (2) open-ended 
questions to entice answers to learners' own problems; (3) a commitment to political change fostering more egalitarian societies. A key component of popular education is practice, which revolves around the idea of act upon the knowledge acquired toward a more just and equal society (Crowther, Galloway, \& Martin, 2005).

When popular education is applied to this study, the researcher identifies the learners as the documentary's audience and subsequently the interviewees. Participants of this research engage in the learning process when they watch the documentary for the first time and listen to the story of the restavè woman depicted in the film. The process of popular education takes place when participants answer the questionnaire as an attempt to organize their experiences and better understand the restavèk phenomenon in Haiti.

\section{Storytelling}

Storytelling is the practice of sharing narratives with self, others, or with researchers (Vannini, 2012, p. 935). Narratives are stories about personal and/or collective memories that result in storytellers reliving previous experiences with the aim to better make meaning of them. Thus storytelling can be viewed as means for ordering potentially disconnected experiences into mutually interrelated, meaningful episodes of a larger plot, be that a biography or a common history (Vannini, 2012, p. 936).

Furthermore, Vannini (2012) emphasized the importance of discursive frames that shape narratives based on the storyteller's cultural background, morals, and common popular knowledge. Researchers must understand narratives considering the storyteller's encoding and interpretation of his/her memories based on cultural conventions (Vannini, 2012). The value of storytelling lays on the fact that people negotiate their identity through the re-count of their narrative and thus construct their reality based on how they verbalize and organize their lived events (Vannini, 2012).

Furthermore, when studying storytelling, films are texts that can be analyzed and meaning can be negotiated through personal stories of depicted subjects (Huczynski \& Buchanan, 2004). Therefore, Blooming Hope (2010) is a documentary film that depicts a woman who was a victim of the restavèk phenomenon in Haiti and who shares her narrative in the film. In addition, each of the participants tell their personal stories while engaging in a process to better understand their past experiences with restavèk children and often as an attempt to narrate an apologetic discourse for themselves.

\section{Methodology}

This ethnographic study consisted of in-depth personal interviews. Participants (1) answered a pre-questionnaire related to personal experiences with restavès; (2) then, participants watched the documentary film Blooming Hope (2010); and (3) they responded to a post-questionnaire related to their perceptions of restavèks after having watched the documentary and having listened the story of Tata Dumasie, the restavè woman featured in the film.

\section{Participants}

The researcher used purposeful sampling to select participants for this study. Each of the six participants approached the researcher after having watched Blooming Hope (2010) at public screenings, and expressed their desire to further discuss the restavèk phenomenon in Haiti. All of the participants had restavèks living with them in their homes and are recognized as guardians in this study. The researcher assigned different names to each of the participants for this paper. They all signed consent forms. 


\section{Instrument}

This study consists of a pre-questionnaire, a screening of Blooming Hope (2010), and a post-questionnaire. The pre-questionnaire inquires about the participants' experiences with restavèk children in Haiti. As participants tell their stories, they reconstruct their realities and awareness of the restavèk phenomenon.

Blooming Hope (2010) is a documentary film that portrays three long-term sustainable projects in the Northwest region of Haiti. One of the projects is a women's artisan cooperative that features Tata Dumasie, a woman who grew up as a restavè in Port-de-Prince and is a member of the artisan cooperative. She tells her personal story as a restavè and demonstrates how her artwork represents a sustainable economic solution for her family of five children.

When Tata Dumasie was six years old, her mother sent her to Port-de-Prince to live with a family as a domestic servant. The family, or guardians, took Dumasie and promised her mother that they would offer her food, shelter, and education in exchange of her work. Dumasie worked for this family for six years. She had to do all the house chores and walk the children of the family to school every day. When she tells her story in the documentary film, she cries while recalling memories of her physical pain and hard work. Her back and feet hurt so much of ironing clothes and cleaning all the time. The most traumatic fact of her experience as a restavè child is that her guardians never sent her to school. She assures that if she had been sent to school, she would have been able to offer a better future for her kids. On the contrary, she states "sometimes my children are hungry, and I do not have any food to give them" (Moyano \& Rosero, 2010).

Finally, the post-questionnaire attempts to bring to the surface the experience of participants after watching Blooming Hope (2010) and hearing the personal story of Tata Dumasie growing up as a restavèk child.

\section{Results}

The researcher used content analysis to organize the raw data collected through the study. This section consists of participants' experiences with restavèks followed by their reactions after watching Blooming Hope (2010). The major themes identified in this content analysis through the pre-questionnaire are restavèks' origins, duties, and abuse. Abuse branches into emotional, physical, and sexual abuse. Themes identified through the post-questionnaire after having watched Blooming Hope (2010) are discomfort, regret, and awareness.

\section{Participants' Experiences with Restavèks}

The researcher organized the personal experiences of participants with restavèks in to three themes based on their responses, such as restavèks' origin, duties and abuse.

\section{Restavèks' Origin}

All of the participants resided in Port-de-Prince when they had restavèks living with them in their homes. When asked about the process of recruiting restavèks as servant domestic workers, they said that most of them came from the countryside. Some of the participants' families found the children homeless in the streets and took them as restavèks. In other cases, mothers offered their children to be taken as restavèks.

Rachel: Growing up I remember having many restavèks living with us. Some of them lasted a really long time, like about eight to nine years, and some of them just months or weeks. The first restavèk that I ever knew was given to my mom because her parents were deceased. She was from Cap-Haitian. She grew up with us, went to school, and even got 
pregnant with a baby boy while living in my house. The other ones also came from the countryside because their families were not able to care for them. My mom found two of the restavès of my house right outside our block in Port-au-Prince.

Alcid: I was probably eight years old. This woman came and she had a young little girl. She may have been 11 years old. I did not know what was going on. My mom gave her food. Before I knew it, the mother left and she stayed with us. She had a bag of belongings with her.

Some of the restavèks are children who do not have parents or caregivers. In other cases, their parents cannot sustain them and prefer to send them away to be domestic servants as a solution for subsistence.

\title{
Duties
}

Most of the restavèks are assigned hard working routines. Some of them are responsible for accomplishing particular house chores such as cooking, laundry, or cleaning. Alcid remembers that "they wake up before everyone else around 4:30 a.m. or 5:00 a.m. They make coffee, make beds, do the laundry, iron clothes, cook, and constantly clean". Other Restavèks are assigned to assist and accompany their guardian's children. Paulmarie says "She [her restavèk] removed my uniform, bathed me, was behind me everywhere. She was just like my mother".

\begin{abstract}
Abuse
The researcher classified abuse into three themes such as emotional, physical, and sexual abuse.

Emotional Abuse. Most of the restavèks are victims of emotional abuse. Participants explained that there is always a clear power difference between restavèks and guardians' family members. Even though some guardians attempt to treat restavèks with as much dignity as possible, there is always the clear line that identifies them as servants and inferior to anyone else in the family. Therefore, guardians constantly remind them that they are restavèks, evidently implying the derogatory meaning of the term. Alcid recalls situations of emotional abuse against the restavèks, "My sister always reminded them that she had education that they could not get because of their restavèk status". In the story of Dumasie, the fact that her guardians did not send her to school was the most traumatic episode of her life. "I also experienced my dad yelling at them at times and not treating them fairly when they did not get the job properly done-Rachel”.
\end{abstract}

Physical Abuse. Restavèks are expected to perform difficult house chores that usually young children are not capable of accomplishing. As a result, guardians abuse their Restavèks physically when they do not perform house chores as expected. Paulmarie recalls that her aunt mistreated one of the restavèk children, "They are expected to perform difficult house chores that usually young children are not capable of accomplishing. She did not send her to school. She used to beat her every time she did not do anything right. She was a little girl and she could not do things right [as an adult]". All of the participants agree that the reasons that lead guardians to abuse restavè children rest on their inability to perform house chores. "My mom used to spank her every time she did something wrong or did not do her chores-Alcid". Physical abuse escalates to episodes like what Rachel recalls, "My sister once threw hot water at her because she had not done her chores".

Sexual Abuse. Sexual abuse is different from emotional or physical because it is not based on the restavèks' inability to perform domestic duties. Sexual abuse against restavèks is a major issue in the Haitian community. Some of the participants claim that male guardians "use" female restavèks to satisfy their sexual needs. All of the participants knew about an episode of sexual abuse against their restavèks. 
Paulmarie: Usually males in the family rape the restavè girls. I heard about a case in my neighborhood. They [restavèks] do not talk about it. These children are so scared that they do not tell the adults that they are molested.

Alcid afflicted with anguish recalled occasions when he sexually abused the female restavèks living in his house.

Alcid: I remember me touching the girls. I was 13 years old. I was the result of my society. Superiority allows me to dehumanize them and mom justified the behavior by saying that it was a male necessity or desire.

Two participants reported that sexual abuse against restavèk girls was socially accepted. “...I remembered her telling my auntie about what my cousin did and they never believed her and when she got pregnant, they said she went looking for it-Rachel". Restavèks do not have custodians who can protect them, which facilitates male adults to sexually abuse them. They know that if the female children denounce the abuse, no one will even care to defend them.

\section{Participants' Reactions after Watching Blooming Hope}

The researcher classified responses of participants after watching Blooming Hope (2010) into three themes such as discomfort, regret and awareness.

\section{Discomfort}

The Restavèk phenomenon in Haiti is an accepted practice rarely publicly discussed. "I knew about it [the reality of the Restavèks], but every time you hear a story is like something new. It makes you really uncomfortable-Paulmarie". Restavèks are not expected to be active communicators, but are rather constrained to listen and obey their guardians' orders. Therefore, they do not have the right to voice their concerns. "It was difficult to see. Yes, I had seen the restavèks speaking on international media. They never talk about these stuff-Crystal".

\section{Regret}

All of the participants regret having physically or psychologically mistreated the Restavèk children. "I regret all the times that I may have ever disrespected one of them or made them feel less than me-Rachel." Before watching Blooming Hope (2010), participants had never consciously evaluated the restavèk phenomenon. After seeing Dumasie telling her story as a restavèk in the documentary, participants remembered their experiences with restavèks and feel guilty about their abuse against them. "In her voice I hear the cry of these girls asking for justice and I feel responsible for it... It is as if she was talking to me and telling me why you did this to me-Alcid".

\section{Awareness}

Most of the participants had never seen a woman telling her story as a restavèk from her perspective. "After watching Blooming Hope (2010), I understand their [restavèks] story and their struggle-Rachel". Dumasie represents all the children in Haiti who face domestic slavery. When audiences see Dumasie telling her afflicting story, they are able to recognize her as a human being rather than a property or object that serves. "She put a face to the suffering of all these kids. They do not have voices... they are not given the space-Alcid".

Alcid said that Blooming Hope (2010) deeply impacted him because he was able to reflect about the 
restavèk phenomenon in Haiti. Also, he confessed that he had never spoken to anyone about his experiences with the restavèk children and his great regret. "It helps me to confess this past that very few know, because I can make sense of what I did, and really reflect on how wrong I was-Alcid”.

Participants recognized the impact of Blooming Hope (2010) as an instrument to spark dialogue and to uncover the unheard violence against children. "The story of Dumasie brings to light the unheard personal story of Haitian restavèks-Crystal”.

Arthur: The story of Dumasie is the movie to me because it gives a voice to all the Restavèks who are speechless in our Haitian society. This demonstrates the power struggle that we face in our modern society in Haiti.

Furthermore, most participants also realized the permanent psychological distress of Dumasie and most restavèks as a result of their experiences as domestic servants. "Even though she [Dumasie] made a way out of it, she lived something that destroyed her real person and she will not get counseling-Paulmarie". Alcid reflected that he has become a successful professional because he was allowed to have dreams and accomplish them; while the numerous restavèks that served him throughout his life were never allowed to dream and were just struggling to satisfy their basic needs. He concludes, "I am who I am today thanks to all the work that restavèks did for me along the years. Now, I wonder how their lives unfolded”.

\section{Discussion}

This research demonstrates that documentaries can be used as tools for popular education to facilitate members of featured communities to engage in reflection of social issues portrayed. All of the participants of this study felt the urge to discuss the restavè phenomenon with the researcher after watching Blooming Hope (2010). They were willing to share their most intimate personal stories to better understand the restavèk phenomenon and to find a solution for this entrenched social problem. This study is the result of a request of Haitian audiences who watched Blooming Hope (2010) and were eager to engage in conversation about the restavèk phenomenon in Haiti.

Narratives told by individuals who are restavèks or were restavèks in their childhood are significant for the re-construction of the social fabric of Haiti as they serve as vehicles to connect the dichotomy of social differentiation between the poor and the rich (Vannini, 2012). One of the most important outcomes of this study is that participants came to the realization that restavèks suffer an abysmal social subjugation that neglects their freedom to develop personally and professionally.

Most of the participants identified episodes of mistreatment of the restavèks that someone else had performed. Some of them mentioned family members or neighbors treating the restavèks poorly. However, only one participant recognized that he had mistreated the restavèks while growing up and confessed that he had sexually abused the female restavèks living in his house. This may be the result of the collective shame experienced in the Haitian community for such atrocious crimes against children, but yet an accepted practice.

Restavèk girls are often called la pou sa, a Creole term meaning "available for that" which defines girls as sexual objects at the disposition of the men or boys of the household. Clair (1993) and Townsley and Geist (2000) stated that this type of sexual harassment is the result of the hegemonic discourse of an oppressive system against the restavèk children. 
Another outcome of this study is that participants came to become aware of the severity of the restavè phenomenon in Haiti through a process of discomfort, regret and awareness.

This study reveals that this sexual abuse breeds two kinds of victims: (1) female restavèks who are sexually molested and (2) men who are socially pressured to sexually abuse the girls. Therefore, violence resulting from the restavè phenomenon produces a volatile social composition of individuals who constantly regret their obscure past. Popular education serves as a tool to confess victims' past and liberates them from such traumatic aggression.

Further research must be dedicated to child modern day slavery. In addition, film producers and directors should use storytelling to portray narratives of victims of child modern day slavery, who are often socially neglected. Such documentary films can result in social movements that ignite social consciousness and change.

\section{Conclusion}

Historically adopted practices are challenged when the human story is brought to the surface. Even though Haiti became a free republic as a result of the revolution of the slaves over their ruling class, two hundred years later, Haiti still endures practices of oppression commonly known in colonial times. And, the restavèk phenomenon can be best described as the result of a prevalent colonization of the ruling class over the most disempowered group of any nation: its children. This ethnographic research concludes that documentary films serve as tools for popular education. Furthermore, narrative discourse can transform guardians' perceptions of the restavèk phenomenon.

\section{References}

Article I(d) quoted in Basic Documents of Human Rights (Ed.). (1992). Brownlie, I. Oxford: Clarendon Press.

Balsari, S., Lemery, J., Williams, T. P., \& Nelson, B. D. (2010). Protecting the children of Haiti. The New England Journal of Medicine, 362(9), 25. Retrieved from http://dx.doi.org/10.1056/NEJMp1001820

Bell, M. S. (1995). All souls rising. New York: Pantheon Books.

Bracken, A. (2006). Haiti's children pay the price of poverty. NACLA Report on the Americas, 39(5), 22-25. Retrieved from http://search.proquest.com/docview/202681721?accountid=14129

Campbell, G., Miers, S., \& Miller, J. C. (Eds.). (2011). Child slaves in the modern world. Athens, OH: Ohio University Press.

Clair, R. P. (1993). The use of framing devices to sequester organizational narratives: Hegemony and harassment. Communication Monographs, 50, 113-137.

Crowther, J., Galloway, V., \& Martin, I. (Eds.). (2005). Popular education: Engaging the academy: International perspectives. Leicester, UK: National Institute of Adult Continuing Education England and Wales (NIACE).

Dubois, L., \& Garriqus, J. D. (2006). Slave revolution in the Caribbean, 1789-1804: A brief history with documents. New York: Bedford Press.

End Slavery Now. (2015). Restaveks: Haitian slave children. Retrieved January 9, 2015, from http://endslaverynow.org/learn/photos/restaveks-haitian-slave-children

Fischer, S. (2004). Modernity disavowed: Haiti and the cultures of slavery in the age of revolution. Durham, NC: Duke University Press.

Freire, P. (1970). Pedagogy of the oppressed. New York: The Continuum International Publishing Group.

Huczynski, A., \& Buchanan, D. (2004). Theory from fiction: A narrative process perspective on the pedagogical use of feature $\begin{array}{lllll}\text { film. Journal of } \quad \text { Management } & \text { Education, 28(6), } & \text { 707-726. } & \text { Retrieved }\end{array}$ http://search.proquest.com/docview/195715326?accountid=14129

Moyano, M., \& Rosero, F. J. (2010). Blooming hope: Harvesting smiles in port-de-Paix, Haiti [DVD]. Bloominghope.org

Townsley, N. C., \& Geist, P. (2000). The discursive enactment of hegemony: Sexual harassment and academic organizing. Western Journal of Communication, 64(2), 190-217. Retrieved from 
http://search.proquest.com/docview/202695390?accountid=14129

Vannini, A. (2012). Stories and storytelling. Encyclopedia of Communication Theory (Ed.). Thousand Oaks, CA: SAGE, 2009.

935-37. SAGE Reference Online. Web. 2 Jul.

Wagner, L. R. (2008). When the one who bears the scars is the one who strikes the blow: History, human rights, and Haiti's restaveks. The University of North Carolina at Chapel Hill. Pro-Quest Dissertations and Theses, 64. Retrieved from http://search.proquest.com/docview/288169168?accountid=14129

UNICEF. (2015). Haiti at glance. Retrieved January 9, 2015 from http://www.unicef.org/infobycountry/haiti_statistics.html

United Nations Statistics Division. (2015). Haiti. Retrieved January 9, 2015, from https://data.un.org/CountryProfile.aspx?crName=Haiti; http://www.unicef.org/infobycountry/haiti_61518.html 